\title{
Sistem Informasi Manajemen (SIM) Hafalan Al- Qur'an Berbasis Codeigniter Framework
}

\author{
Janu Ilham Saputro ${ }^{1}$ \\ Praditya Aliftiar"2 \\ Ahmad Syaefud Daeroby ${ }^{3}$ \\ ${ }^{1,2,3}$ Program Studi Sistem Informasi Fakultas Sains dan Teknologi Universitas Raharja \\ E-mail: ${ }^{1}$ janu@ raharja.info, ${ }^{2}{ }^{2}$ praditya.aliftiar@ raharja.info, ${ }^{3}$ daeroby@ raharja.info
}

\begin{abstract}
ABSTRAK
Dari waktu ke waktu berkembangnya teknologi terasa begitu pesatnya.Diantara banyaknya teknologi, website termasuk teknologi yang banyak digunakan karena dapat diakses dengan mudah melalui perangkat PC ataupun smartphone. Banyak tools yang dibuat untuk memudahkan web developer dalam mengembangkan website. Salah satunya adalah framework Codeigniter yang dibangun dengan bahasa PHP.Tools ini bersifat gratis dan dapat mempercepat pengembangan website.SMA Islam Allayyinah merupakan salah satu instansi pendidikan yang terletak dikawasan kabupaten Tangerang.Pada SMA Islam Al-layyinah terdapat muatan lokal tahsin yang wajib diikuti oleh semua siswa.Tahsin mengharuskan semua siswa untuk menghafalkan ayat Al-qur'an lalu menyetorkannya kepada guru. Sistem manajemen hafalan Al-qur'an yang berjalan saat ini masih kurang optimal karena masih manual dengan cara ditulis. Berdasarkan permasalahan yang ada maka dirancang sistem manajemen hafalan Alqur'an berbasis web.Dalam pengumpulan data, digunakan dengan metode wawancara, observasi dan studi pustaka.Serta metode analisa PIECES. Pemodelan sistem dilakukan dengan metode UML dan perancangan sistem menggunakan toolsframework Codeigniter sebagai server-side dan Bootstrap sebagai client-side.
\end{abstract}

Kata kunci : Sistem informasi manajemen, PIECES, Codeigniter

\begin{abstract}
From time to time the development of technology feels so fast. Among the many technologies, websites are among the technologies that are widely used because they can be accessed easily via a PC or smartphone. Many tools are made to make it easier for web developers to develop websites. One of them is the Codeigniter framework which is built in the PHP language. These tools are free and can speed up website development. Al-Layyinah Islamic High School is an educational institution located in the Tangerang district. At Al-Layyinah Islamic High School there is a local content of tahsin which is mandatory for all students. Tahsin requires all students to memorize the verses of the Al-quran then submit it to the teacher. The current Al-quran memorization management system is still not optimal because it is still written manually. Based on the existing problems, a web-based memorization management system was designed. In data collection, used by interviews, observation, and literature study methods. As well as the PIECES analysis method. System modeling is done by using the UML method and system design using Codeigniter framework tools as server-side and Bootstrap as client-side.
\end{abstract}

Keyword: Management information system, PIECES, Codeigniter

\section{PENDAHULUAN}

Pada era saat ini, teknologi website berkembang sangat pesat. Website banyak digunakan karena dapat diakses dengan mudah melalui perangkat PC ataupun smartphone. Banyak tools yang dibuat untuk memudahkan web developer dalam mengembangkan website. Salah satunya adalah framework codeigniter yang dibangun dengan bahasa php.Tools ini bersifat gratis dan mempercepat pengembangan website. Codeigniter merupakan web framework dengan arsitektur MVC (model-view-controller) yang membuat code program lebih terstruktur dan ringkas, sehingga mempercepat proses pengkodean 
program. Dan juga dukungan komunitas yang luas di Indonesia membuat framework ini banyak digunakan untuk keperluan project website.

Proses manajemen hafalan Al-qur'an pada SMA Islam Al-layyinah saat ini masih kurang optimal, karena masih manual, dengan pencatatan pada media kertas. Karena kertas dapat mudah hilang dan rusak serta Guru sulit untuk memonitoring perkembangan hafalan Siswa. Oleh karena itu peneliti mengusulkan suatu sistem berbasis web yang dapat diakses oleh user secara cepat dan mudah. Dengan adanya sistem berbasis web diharapkan Guru dapat dengan cepat menginput data hafalan siswa serta dengan adanya laporan secara real-time dapat membantu Guru dalam memantau kemampuan hafalan para Siswa.

\section{METODE PENELITIAN}

\subsection{Metode Pengumpulan Data}

Untuk memperoleh data, digunakan metode-metode sebagai berikut :

a. Metode Observasi

Observasi dilakukan dengan mendatangi langsung tempat objek penelitian yaitu SMA Al-layyinah yang beralamat di Jalan Cijengir, Binong, Kec. Curug, Tangerang, Banten untuk menganalisa sistem dan melihat permasalahan yang terjadi.

b. Metode Interview

Penulis melakukan interview dengan memberikan beberapa pertanyaan kepada narasumber, sehingga didapatkan data yang dibutuhkan.

c. Metode Studi Pustaka

Penulis melakukan studi pustaka guna mencari referensi yang bersumber dari buku, jurnal dan lainnya.

\subsection{Metode Analisa}

Dalam menganalisa sistem yang dibuat, menggunakan metode PIECES, yang merupakan kerangka untuk mengklasifikasikan permasalahan, peluang, dan arahan yang ada pada lingkungan sistem.[1]

\subsection{Metode Pemodelan Sistem}

Metode UML (Unified Modelling Languange) digunakan dalam membuat pemodelan sistem.UML merupakan suatu bahasa grafis yang dapat dignakan dalam pemodelan sistem serta mendokumentasikan suatu sistem. [2]

\subsection{Metode Perancangan Sistem}

Dalam merancang sistem, peneliti menggunakan tools framework codeigniter sebagai server-side, dan bootstrap sebagai client-side serta Mysql sebagai penyimpanan data. Codeigniter menggunakan pendekatan MVC (model, view, controller) yang memisahkan antara logika, presentasi dan proses. [3]

\subsection{Literature Review}

1. Penelitian yang dilakukan oleh Saiful Habib (2016), berjudul "Pengembangan Sistem Informasi Tahsin Tahfidz Al Qur'an (Sitahta) Berbasis Web Di Smait Ihsanul Fikri Mungkid”. Metode yang digunakan adalah metode analisa functional dan metode prototype. Tujuan penelitian ini untuk meningkatkan pengolahan data kemajuan hafalan siswa. [4]

2. Penelitian yang dilakukan oleh Dwi Rolliawati,dkk (2017), dengan judul "Desain Prototype Sistem Informasi Hafalan Al Quran Berbasis Perspektif HCI”. Metode yang digunakan adalah metode R\&D level 1. Tujuan penelitian ini untuk mengembangkan prototipe yang dapat meningkatkan produktivitas dan mempermudah proses bisnis yang ada di UPTQ. [5]

3. Penelitian yang dilakukan oleh Ahmad Fikri Fajri (2020), dengan judul "Sistem Informasi Setoran Hafalan Al-Quran Rumah Tahfiz Al Yusra Dengan Notifikasi SMS". Observasi, wawancara serta 
riset laboratorium digunakan sebagai metode pengumpulan data. Penelitian ini menghasilkan suatu sistem yang dapat melakukan monitoring hafalan. [6]

4. Penelitian yang dilakukan oleh Adiama Septiara (2019), dengan judul "Pengembangan Aplikasi AlQuran Untuk Membantu Hafalan Al-Quran Secara Mandiri Menggunakan Metode Tikrar". Tujuan penelitian ini yaitu mengembangkan aplikasi yang dapat mempermudah dalam membaca dan menghafal Al-qur'an. [7]

\section{HASIL DAN PEMBAHASAN}

\subsection{Rancangan Diagram $U M L$}

a. Use Case Diagram

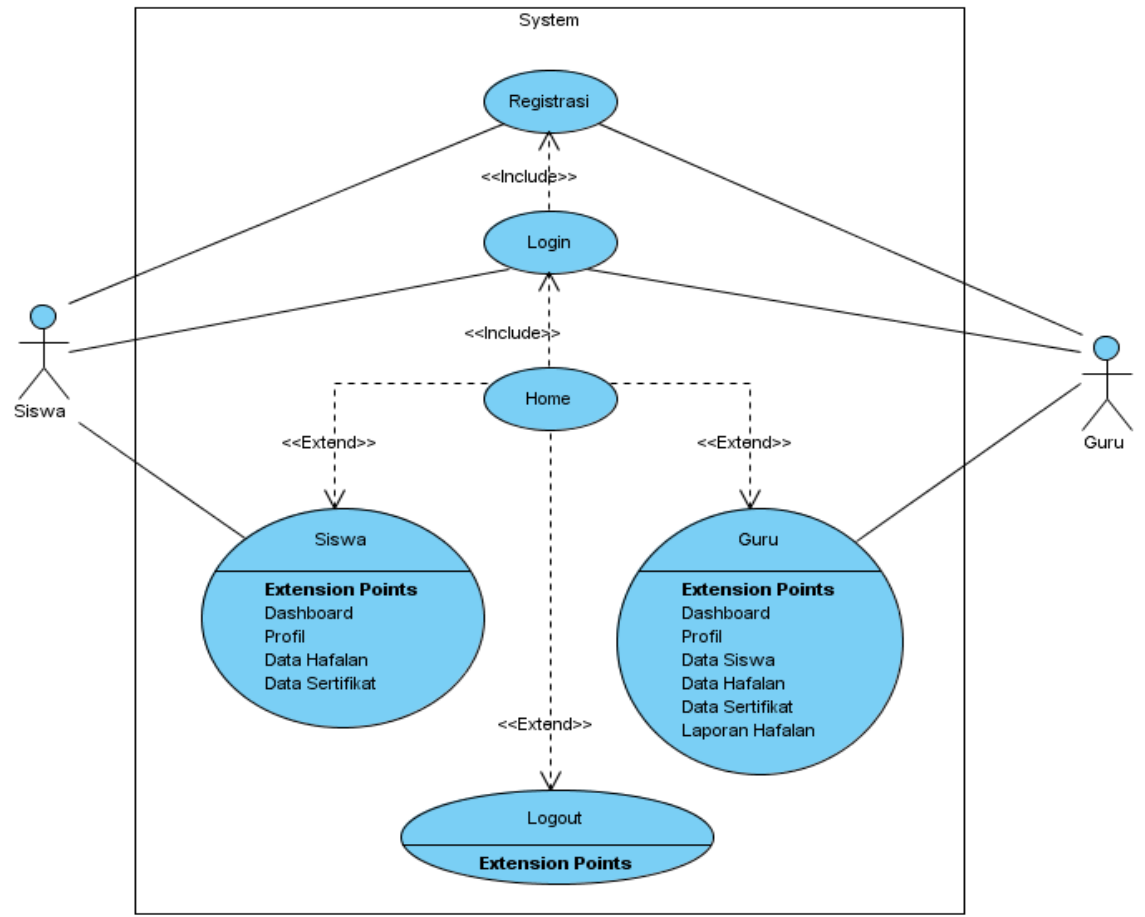

Gambar 1.Use Case Diagram

Berdasarkan gambar 1 use case terdapat :

1) Terdapat 1 sistem, yaitu sistem manajemen hafalan Al-quran.

2) Terdapat 2 actor, yaitu guru dan siswa.

3) Terdapat 6 use case, yaitu registrasi, login, home, siswa, guru dan logout.

4) Terdapat 11 extend point, yaitu dsashboard, profil, data hafalan, data sertifikat, dashboard, profil, data siswa, data hafalan, data sertifikat, laporan hafalan dan logout. 
b. Activity Diagram Guru

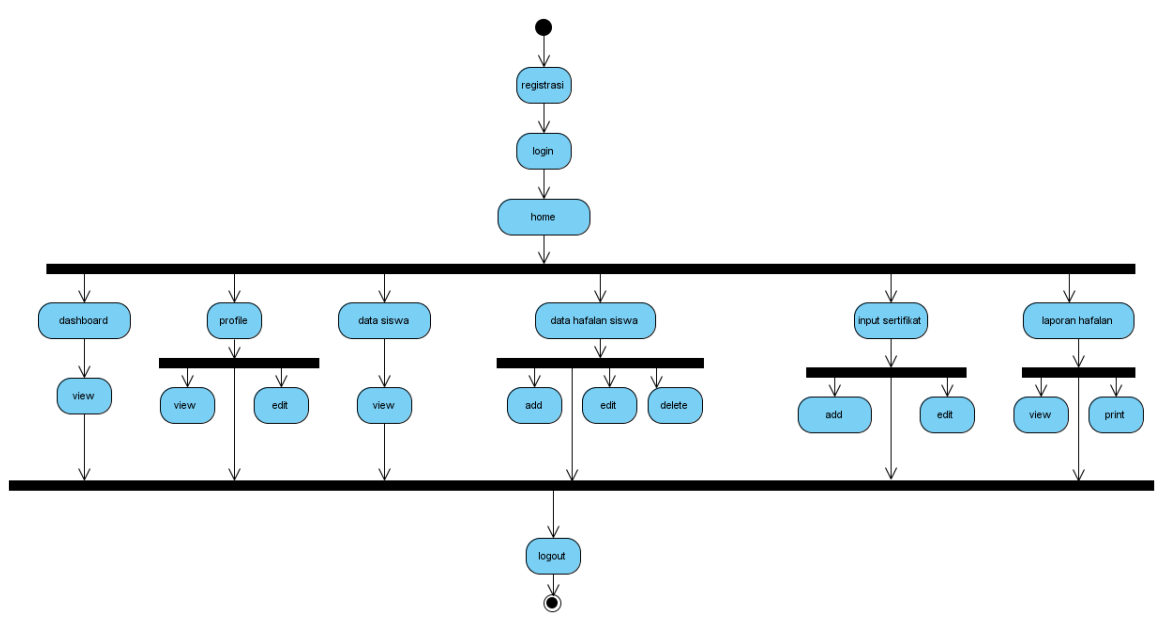

Gambar 2.Activity Diagram Guru

Berdasarkan gambar 2 activity diagram Guru terdapat :

1) 1 initial node, sebagai awalan objek.

2) 21 action, yaitu eksekusi suatu aktivitas.

3) 6 fork node, yang memecahkan satu aliran menjadi beberapa aliran.

4) 1 final node, sebagai akhiran objek.

c. Activity Diagram Siswa

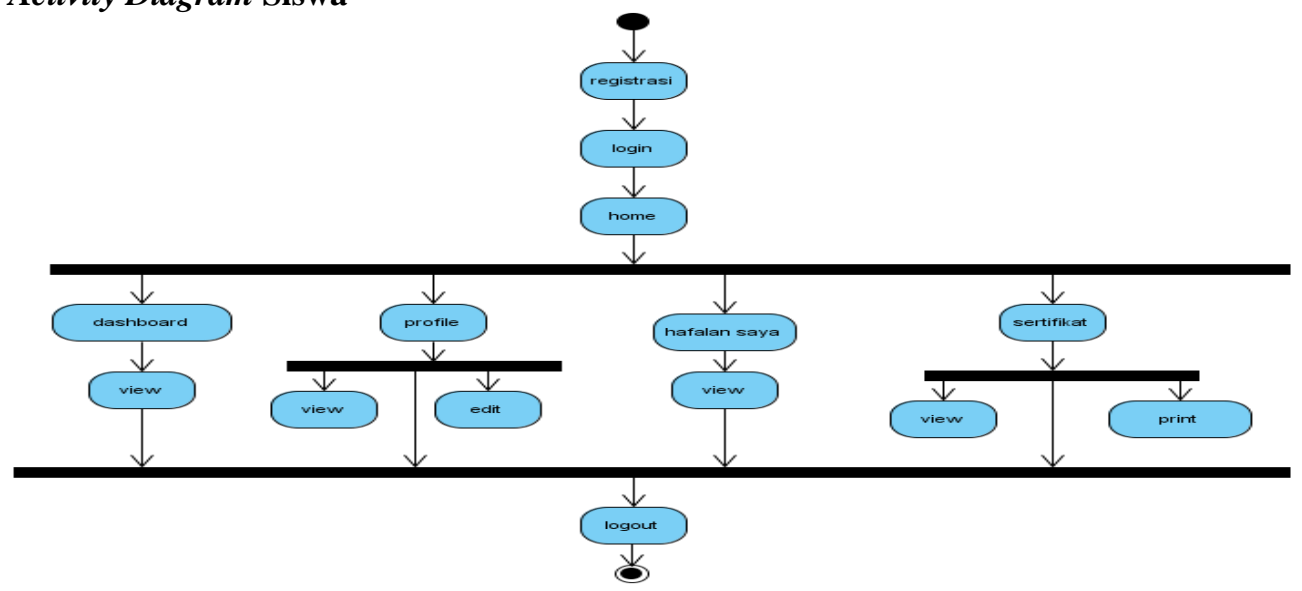

Gambar 3. Activity Diagram Siswa

Berdasarkan gambar 3 activity diagram Siswa terdapat :

1) 1 initial node, sebagai awalan objek.

2) 14 action, yaitu eksekusi suatu aktivitas.

3) 4 fork node, yang memecahkan satu aliran menjadi beberapa aliran.

4) 1 final node, sebagai akhiran objek. 


\section{d. Sequence Diagram Guru}

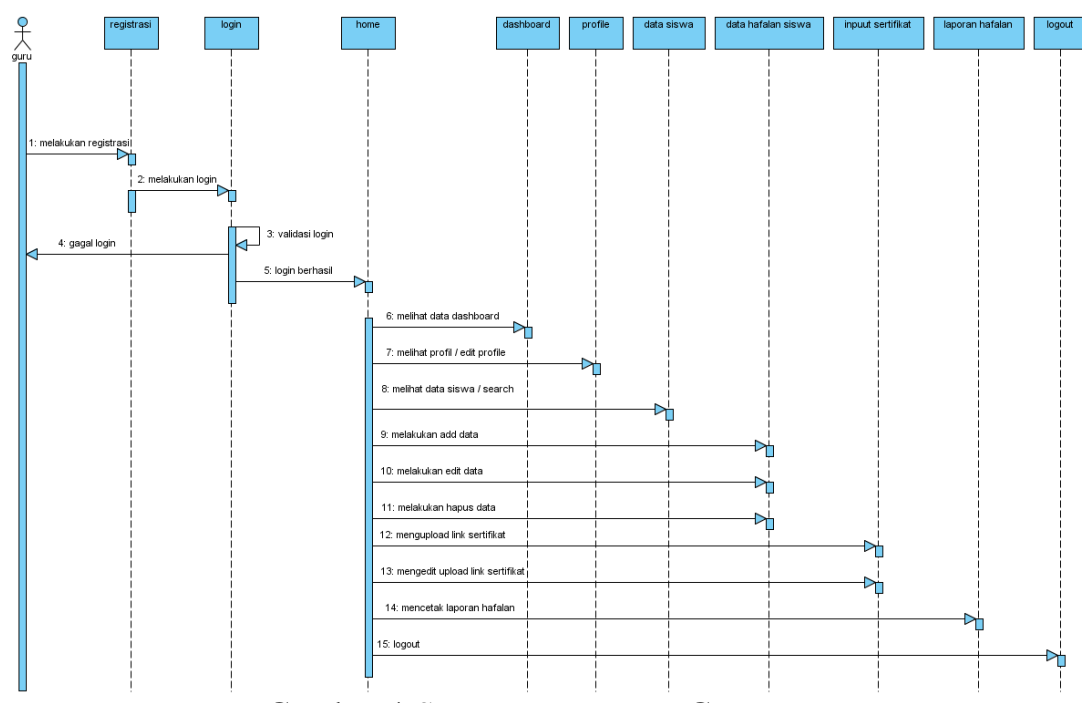

Gambar 4.Sequence Diagram Guru

Berdasarkan gambar 4 sequence diagram Guru terdapat :

1) 1 actor, yaitu Guru.

2) 10 lifeline yang saling berhubungan.

3) 15 message, merupakan komunikasi antar objek

e. Sequence Diagram Siswa

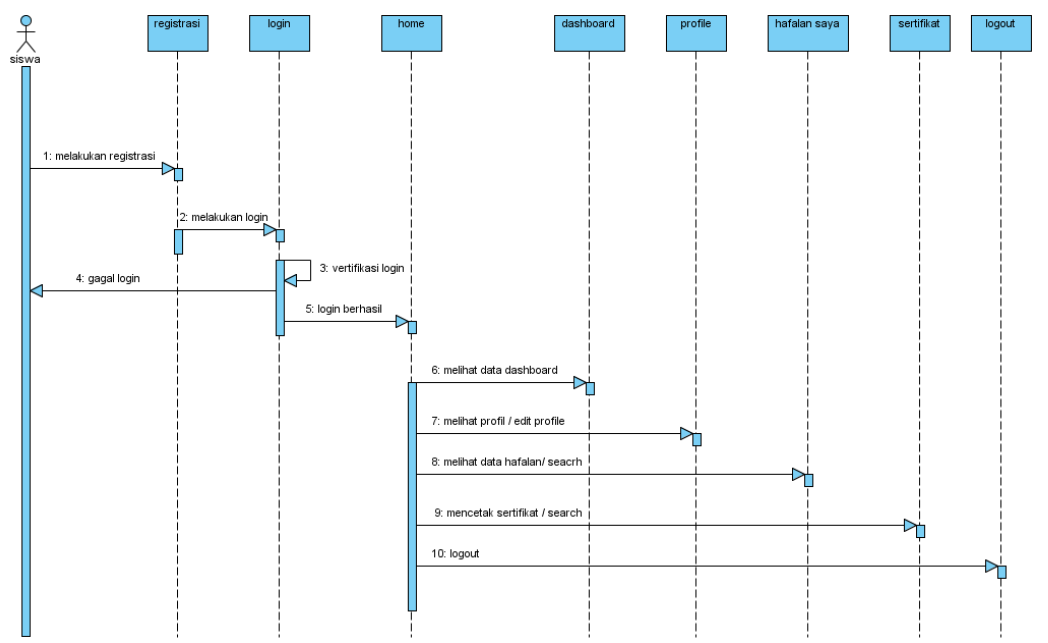

Gambar 5.Sequence Diagram Siswa

Berdasarkan gambar 5 sequence diagram Siswa terdapat :

1) 1 actor, yaitu Siswa.

2) 8 lifeline yang saling berhubungan.

3) 10 message, merupakan komunikasi antar objek. 


\subsection{Rancangan Program}

a. Interface Login

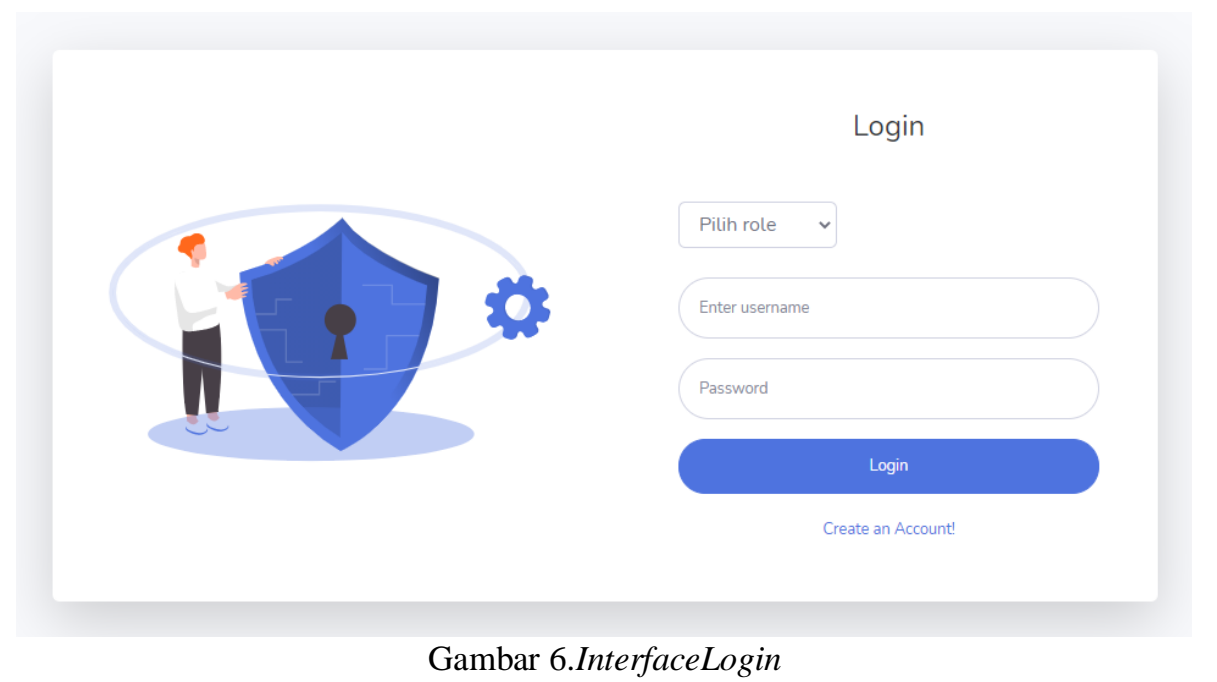

Pada halaman login, pengguna harus memilih role yaitu guru / siswa, serta menginput username dan password untuk masuk kedalam sistem.

\section{b. Interface RegistrasiSiswa}

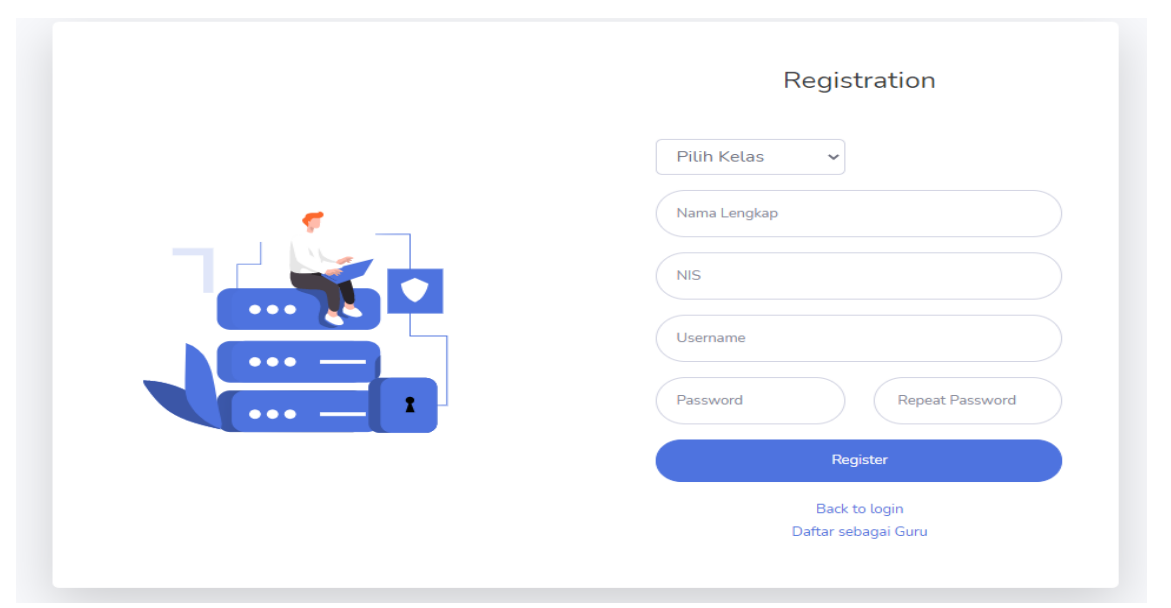

Gambar 7.Interface RegistrasiSiswa

Pada halaman register, Siswa harus mengisi beberapa data yang diperlukan. Jika berhasil registrasi maka Siswa akan diarahkan ke halaman login 


\section{c. InterfaceDashboard Guru}

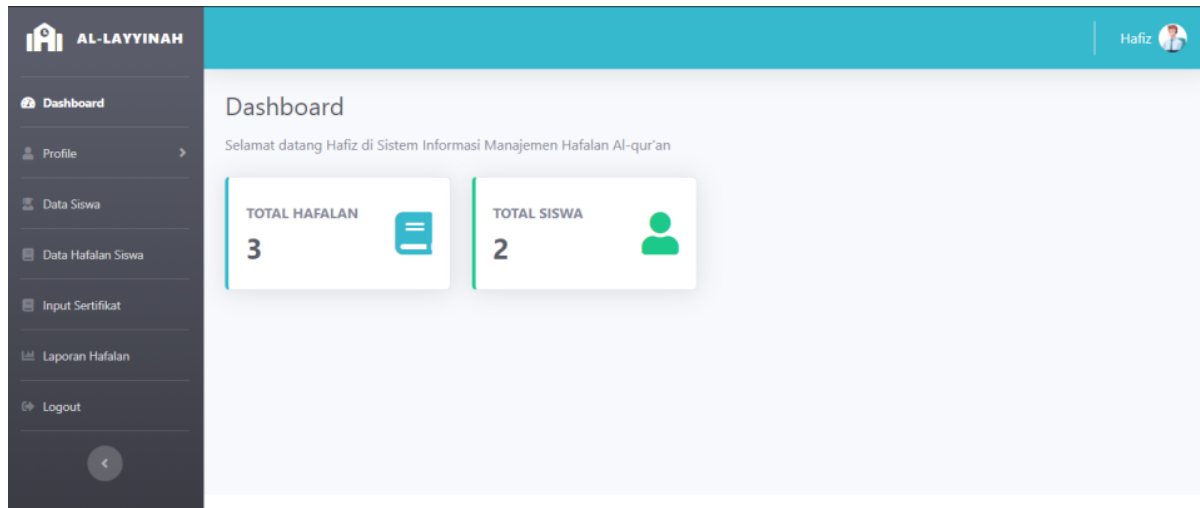

Gambar 8.InterfaceDashboard Guru

Pada halaman dashboard guru terdapat beberapa informasi yang ditampilkan yaitu jumlah siswa dan jumlah hafalan siswa.

\section{d. InterfaceProfile Guru}

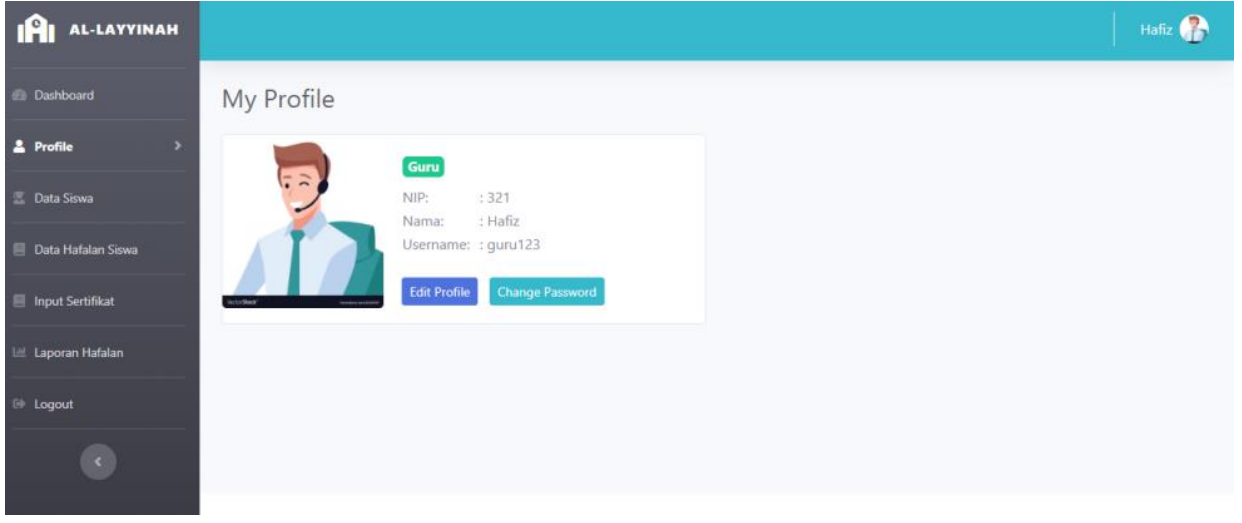

Gambar 9.InterfaceProfile Guru

Pada halaman profile guru, terdapat informasi NIP, nama, username dan foto. Guru juga dapat melakukan edit profile dihalaman ini.

\section{e. Interface Data Siswa}

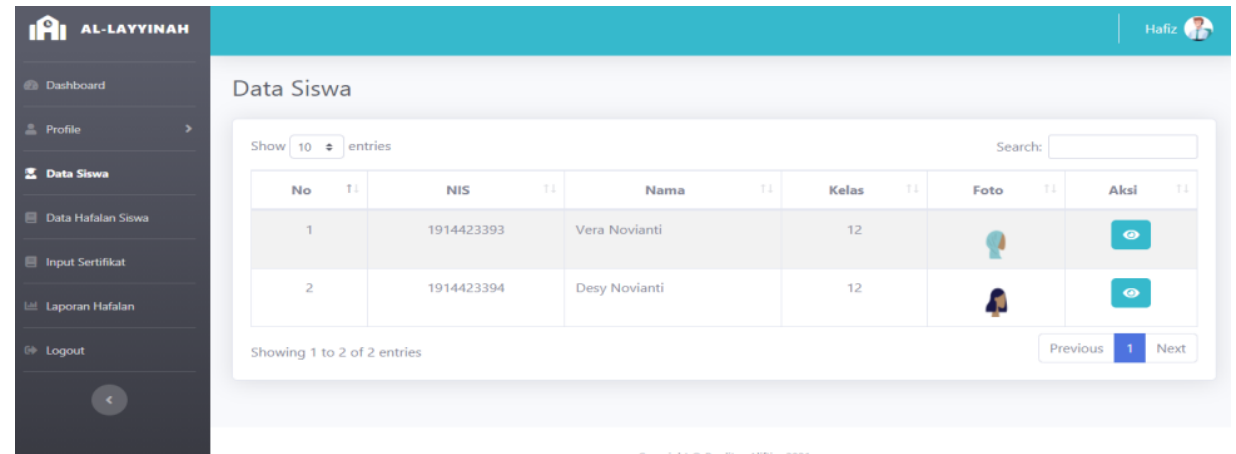

Gambar 10.Interface Data Siswa 
ISSN: 2461-1409

Journal Sensi

Online ISSN: 2655-5298

Pada halaman siswa, terdapat beberapa informasi yaitu nis, nama, kelas, foto dan juga guru dapat melihat detail siswa.

\section{f. Interface Data Hafalan}

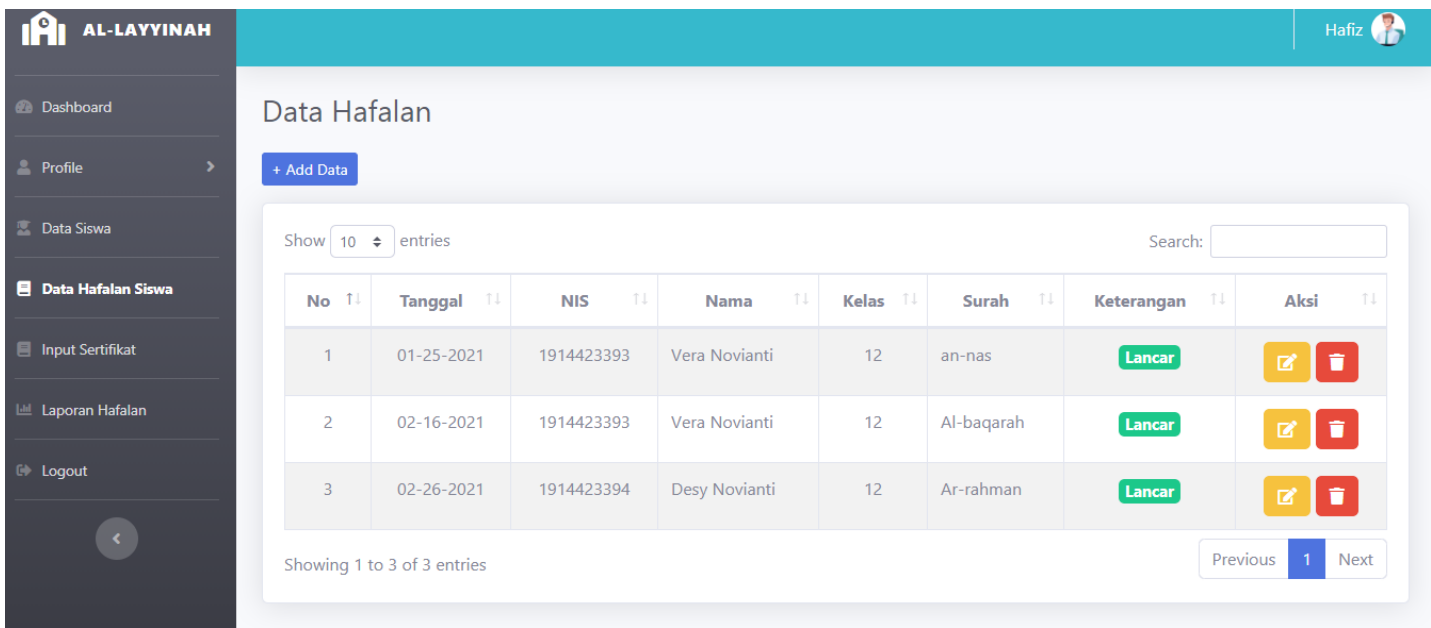

Gambar 11.Interface Data Hafalan

Pada halaman hafalan, guru bisa menambah data, mengupdate dan menghapus hafalan siswa.

\section{g. Interface Input Sertifikat}

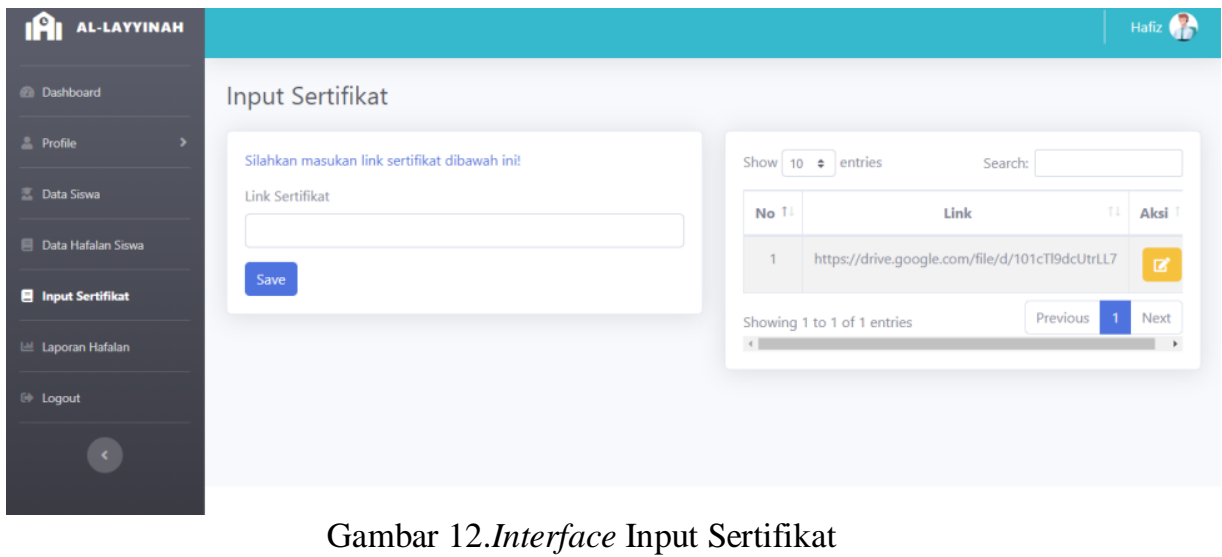

Pada halaman input sertifikat, guru dapat menambah dan mengedit link sertifikat.

h. Interface Laporan 

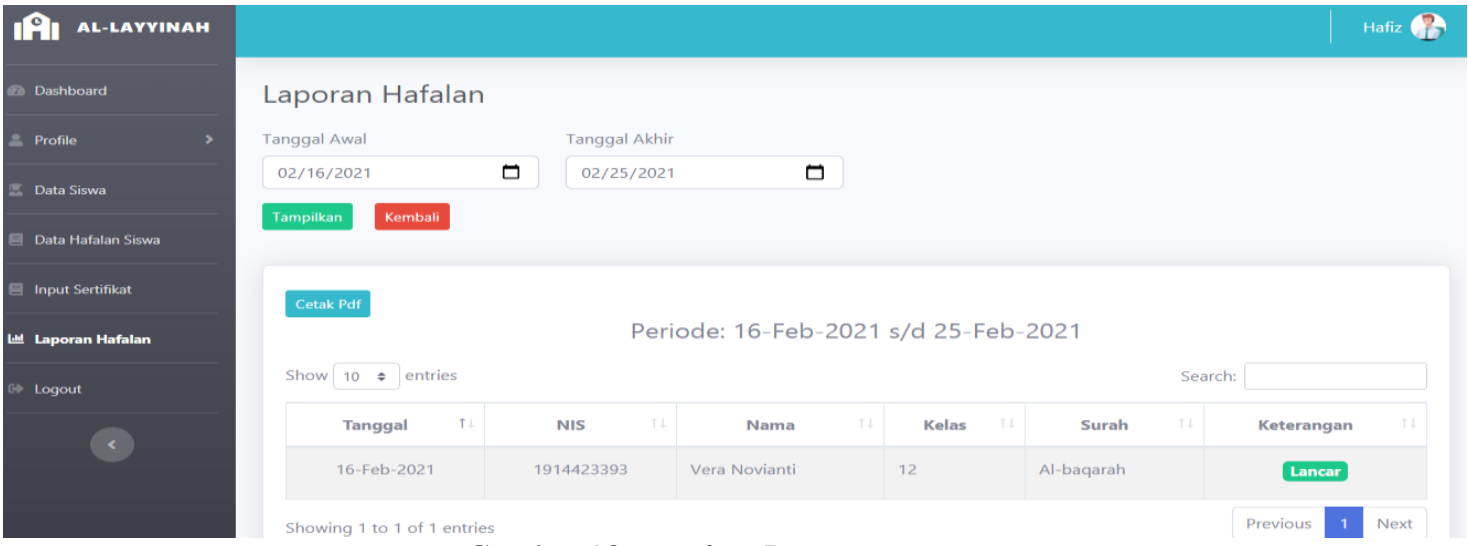

Gambar 13.Interface Laporan

Pada halaman laporan, guru bisa memfilter laporan berdasarkan tanggal dan juga dapat mencetak laporan hafalan.

\section{KESIMPULAN}

Berdasarkan penelitian yang telah dilakukan mengenai sistem manajemen hafalan Al-qur'an yang ada pada SMA Islam Al-layyinah, penulis menyimpulkan sebagai berikut :

1. Sistem manajemen hafalan Al-qur'an yang digunakan saat di SMA Islam Al-layyinah dilakukan dengan manual sehingga masih kurang efektif dan efisien.

2. Penulis menggunakan metode analisa PIECES dalam menganalisa sistem manajemen hafalan yang berjalan saat ini dan $U M L$ sebagai metode pemodelan sistem.

3. Website manajemen hafalan Al-qur'an berhasil dirancang dengan menggunakan tools framework codeigniter sebagai server-sude dan bootstrap sebagai client-side serta database Mysql.

\section{SARAN}

Untuk pengembangan selanjutnya, penulis memberikan beberapa saran sebagai beikut :

1. Melakukan pelatihan kepada siswa dan guru dalam mengoperasikan website manajemen hafalan Al-qur'an.

2. Pemeliharaan sistem harus dilakukan secara berkala, agar sistem dapat berjalan dengan optimal.

3. Sebaiknya dilakukan pengembangan sistem, baik dari segi fitur maupun arsitektur sistem.

\section{DAFTAR PUSTAKA}

[1] Nuryamiyah, N., dan Dewi, A.R. 2018. Analisis Sistem informasi Pengolahan Data Nilai Mahasiswa Menggunakan PIECES Pada Prodi Sistem Informasi SSTH-Medan. Sumatera Utara: Jurnal Sistem Informasi. Vol. 2, No. 2: 37-46.

[2] Mulyani, S. 2016. Metode Analisis Dan Perancangan Sistem. Bandung: Abdi Sistematika.

[3] Endra, R.Y., dan Aprilita, D.S. 2018. E-Report Berbasis Web Menggunakan Metode Model View Controller Untuk Mengetahui Peningkatan Perkembangan Prestasi Anak Didik. Bandar Lampung: Jurnal Sistem Informasi dan Telematika Vol. 9, No. 1.

[4] Habib, S. 2016. Pengembangan Sistem Informasi Tahsin Tahfidz Al Qur'an (Sitahta) Berbasis Web Di Smait Ihsanul Fikri Mungkid. Yogyakarta: Jurnal E-JPTI. Vol. 5, No. 5.

[5] Rolliawati, D., Qomary, L.N., dan Miillah, A. 2017. Desain Prototype Sistem Informasi Hafalan Alqur'an Berbasis Perspektif HCI. Surabaya: Jurnal Systemic. Vol. 3, No. 1: 9-14.

[6] Fajri, A.F., dan Nanda, A.P. 2020. Sistem Informasi Setoran Hafalan Al-Quran Rumah Tahfiz Al Yusra Dengan Notifikasi SMS. Padang: Jurnal J-Click. Vol. 7, No. 1: 18-22. 
[7] Adiama, S., Santoso, N., dan Kharisma, A.P. 2019. Pengembangan Aplikasi Al-Quran Untuk Membantu Hafalan Al-Quran Secara Mandiri Menggunakan Metode Tikrar. Malang: Jurnal JPTIIK. Vol. 3, No. 3. 